\title{
Reading and math abilities of Finnish school beginners born very preterm or with very low birth weight
}

\section{Alanko, Outi}

2017-02

Alanko , O , Niemi , P , Munck, P, Matomäki , J , Turunen , T , Nurmi , J-E , Lehtonen , L , Haataja , L \& Rautava , P 2017 , ' Reading and math abilities of Finnish school beginners born very preterm or with very low birth weight ', Learning and Individual Differences, vol. 54 , pp. 173-183 . https://doi.org/10.1016/j.lindif.2017.01.022

http://hdl.handle.net/10138/236418

https://doi.org/10.1016/j.lindif.2017.01.022

publishedVersion

Downloaded from Helda, University of Helsinki institutional repository.

This is an electronic reprint of the original article.

This reprint may differ from the original in pagination and typographic detail.

Please cite the original version. 


\title{
Reading and math abilities of Finnish school beginners born very preterm or with very low birth weight
}

\author{
Outi Alanko a, Pekka Niemi a,*, Petriina Munck ${ }^{\mathrm{a}, \mathrm{b}}$, Jaakko Matomäki ${ }^{\mathrm{c}}$, Tiina Turunen ${ }^{\mathrm{d}}$, Jari-Erik Nurmi ${ }^{\mathrm{e}}$, \\ Liisa Lehtonen ${ }^{\mathrm{b}}$, Leena Haataja ${ }^{\mathrm{f}}$, Päivi Rautava ${ }^{\mathrm{g}}$, the PIPARI Study Group: \\ a Department of Psychology, University of Turku, Finland \\ b Department of Pediatrics, Turku University Hospital and University of Turku, Finland \\ c Clinical Research Centre, Turku University Central Hospital, Finland \\ d Centre for Learning Research, University of Turku, Finland \\ e Department of Psychology, University of Jyväskylä, Finland \\ f Department of Pediatric Neurology, Children's Hospital, University of Helsinki and Helsinki University Hospital, Helsinki, Finland \\ ${ }^{g}$ Department of Public Health, University of Turku, Finland
}

\section{A R T I C L E I N F O}

\section{Article history:}

Received 1 December 2015

Received in revised form 23 January 2017

Accepted 29 January 2017

\section{Keywords:}

Very preterm birth

Very low birth weight

School readiness

Reading skills

Math skills

\begin{abstract}
A B S T R A C T
Reading and math skills of preterm born (birth weight $\leq 1500 \mathrm{~g}$ or gestational age $\leq 32$ weeks) children and fullterm (FT) children were compared during the first weeks of grade 1 . The participants were 194 preterm born and 175 FT children born between 2001 and 2006.

There were more precocious readers among FT than among preterm students, but even the latter performed close to the national norm. FT and preterm group differences among non-readers were minor with only rapid naming showing a robust difference. Math performance showed a stable difference in favor of FT students and the difference was sustained in the full-scale IQ control. Major brain pathology increased the likelihood of poor scholastic skills, but lower birth weight relative to gestational age did not. Somewhat surprisingly, maternal education was not associated with school readiness skills.
\end{abstract}

(c) 2017 Elsevier Inc. All rights reserved.

\section{Introduction}

It is well established that children born very preterm meet difficulties in their general cognitive development (Aylward, 2002; Hornby \& Woodward, 2009; Johnson, Wolke, Hennessy, \& Marlow, 2011). By definition, a birth before 37 weeks' gestation is labelled as 'preterm'. However, the lower the gestational age is, the higher is the risk for a wide range of developmental problems (for a review, see Anderson, 2014; for a succinct presentation of relevant terms, see Tucker \& McGuire, 2004). Many studies and clinical follow-up programs have chosen the cut-off of 32 gestational weeks, usually referred to as 'very low gestational age' or 'very preterm' as opposed to 'extremely preterm' referring to infants born before 28 weeks' gestation, even if more mature preterm infants also have an increased risk for developmental problems compared to full term infants. Moreover, poor intrauterine growth is also a risk for development (Guellec et al., 2016), which justifies using a birth weight limit regardless of gestational age for choosing a high-

\footnotetext{
* Corresponding author at: Department of Psychology, FI-20014 University of Turku, Finland.

E-mail address: peknie@utu.fi (P. Niemi).
}

risk group. Birth weight below $1500 \mathrm{~g}$, usually referred to as 'very low birth weight', or that under $1000 \mathrm{~g}$ ('extremely low birth weight') put an infant to a risk for developmental problems even during modern neonatology with much improved prospects with preterm infants compared to earlier decades (Gardella et al., 2015). Many preterm born children start school with special educational needs (Hornby \& Woodward, 2009; Litt, Taylor, Klein, \& Hack, 2005; Sucksdorff et al., 2015), with these needs tending to increase along with a shorter gestational age or a more severe growth restriction (Larroque et al., 2011).

Among the prime consequences of preterm birth, a compromised cognitive development has been identified. Children born very preterm have a lower IQ than their full term peers (Saigal, Hoult, Streiner, Stoskopf, \& Rosenbaum, 2000; Schneider, Wolke, Schlagmüller, \& Meyer, 2004), the difference being roughly one standard deviation (Breeman, Jaekel, Baumann, Bartmann, \& Wolke, 2015; Schneider et al., 2004; Stjernqvist \& Svenningsen, 1999). While the association between global IQ and school achievement is well known, the usefulness of IQ as a predictor of learning difficulties has recently been called into question. First, the risk factors for prematurity may differ in different societies. In societies with a strong link between social risk and preterm birth, the growth environment is also likely to affect the occurrence of learning difficulties in addition to the biological, prematurity related 
origins affecting brain development (Gray, Edwards, Schultz, \& Miranda, 2014). Second, preterm birth was associated with adolescents' cognitive profile only in cases of severe antenatal growth restriction or the lowest gestational age (Lundequist, Böhm, Lagercrantz, Forssberg, \& Smedler, 2015). Third, a recent meta-analysis suggests that a lower birth weight is not predictive of global cognitive impairment in children older than five years (Linsell, Malouf, Morris, Kurinczuk, \& Marlow, 2015). Fourth, a prediction based on a global measure does not inform teachers of useful interventions (Decker, Hale, \& Flanagan, 2013).

Consequently, there is a need for predictive measures that are more focused on cognitive skills important to learning in the first grades in school, in other words, those relevant to learning literacy and math. In this vein, the school readiness of very preterm children can be seen as a useful framework tying together influences of biological risks, possibly impaired cognitive skills and unfavorable environmental factors (Pritchard, Bora, Austin, Levin, \& Woodward, 2014). Support has come from recent studies suggesting that extremely preterm children need increased teacher support to compensate for their poor ability to focus on classroom activities (Wong et al., 2014). Moreover, persistent neurological abnormalities during the first year of life predict poorer kindergarten performance in letter-word identification, spelling, and math among extremely preterm children at six years of age (Harmon, Taylor, Minich, Wilson-Costello, \& Hack, 2015). However, contrary to research in school-age achievement, studies on the school readiness skills of preterm born children are still scarce.

In the following, we present findings on reading and math difficulties among very preterm children. We also provide a comparative summary in Appendix 1.

\subsection{Pre-reading skills and reading development}

Consensus prevails that three cognitive skills are paramount to literacy acquisition. Phonological awareness is a bridge between spoken and written language. Letter knowledge reflects a perceived presence of written words in the child's developmental environment. Rapid automatized naming is an indicator of the effectiveness of verbal information processing. Obviously, the prognostic testing should be conducted before formal teaching of reading, preferably no later than during the fall term of Grade 1 . All three factors strongly differentiate, for example, pre-schoolers with a familial risk for dyslexia from children not at risk, starting from the age of 3.5 years (Puolakanaho et al., 2008). Analogously, preterm born children may be supposed to run a similar risk.

Available evidence suggests that five to six-year-old, very preterm children perform less well than full-term children in letter knowledge and phonological skills (Lundequist et al., 2015; Munck et al., 2012; Stjernqvist \& Svenningsen, 1999; Taylor et al., 2011; Wolke, Samara, Bracewell, \& Marlow, 2008; Wolke \& Meyer, 1999). However, a recent Dutch study alludes to a somewhat different pattern with pre-schoolers showing only a tendency toward an inferiority of the phonological skills among very preterm children (Aarnoudse-Moens, Oosterlaan, Duivenvoorden, van Goudoever, \& Weisglas-Kuperus, 2011). Interestingly, when reading has been stabilized by eight years of age and onward, the association between preterm birth and reading deficiency appears to become more diffuse. Some studies report a difference between preterm born and full-term students (Larroque et al., 2011; Lee, Yeatman, Luna, \& Feldman, 2011; Pritchard et al., 2014; Samuelsson et al., 2006; Schneider et al., 2004; Wocadlo \& Rieger, 2007), while in others no difference has been found (Anderson \& Doyle, 2003; Feldman, Lee, Yeatman, \& Yeom, 2012; Hagen, Palta, Albanese, \& Sadek-Bawawi, 2006; McGrath \& Sullivan, 2002; Pritchard et al., 2009; Rickards, Kelly, Doyle, \& Callanan, 2001). There are also mixed findings (Aarnoudse-Moens et al., 2011; Guarini et al., 2010). Only in the subgroup of students with extremely low birth weight does the difference occur consistently as shown by recent studies (Hutchinson,
De Luca, Doyle, Roberts,, \& Anderson, 2013; Johnson et al., 2011; Litt et al., 2012). All things considered, it is reasonable to state that evidence concerning reading development of preterm born children is equivocal.

\subsection{Math skills}

Symbolic number identification is a foundational skill for basic math in the same way as letter knowledge is that for beginning reading. Its level in kindergarten strongly predicts math achievement in first grade (e.g. Martin, Cirino, Sharp, \& Barnes, 2014; Östergren \& Träff, 2013). Another set of strong predictors are various counting skills. An example of basic counting is rote verbal counting from number 1 forward. More advanced counting requires knowledge of the number continuum and is needed in basic arithmetic (e.g. Aunola, Leskinen, Lerkkanen, \& Nurmi, 2004; Nguyen et al., 2016). Counting forward from a given number is involved in basic addition and counting backward from a given number is needed in basic subtraction (e.g. Zhang et al., 2014). Good counting skills are a prerequisite for the development of an arithmetic fact retrieval strategy, which is faster than the mere counting-based strategy (Koponen, Aunola, Ahonen, \& Nurmi, 2007). Measurements of number knowledge, counting ability, and arithmetic fact retrieval were available for the present sample. Studies with more covering sets of predictors have found a considerable overlap between them (e.g. Cirino, 2011; Koponen et al., 2007; Nguyen et al., 2016),

There are only few studies focusing on early mathematical skills of very preterm children. It has been suggested that these children cannot name as many number symbols as the control children (Wolke \& Meyer, 1999) and they have difficulties in numerical reasoning skills (classifying, sorting, comparing and counting of objects) in preschool (Aarnoudse-Moens et al., 2011). The predictive power of counting skills appears particularly strong in the face of concurrent comparison at 9 years of age, and is sustained even after Bonferroni correction and controlling for nonverbal IQ (Simms et al., 2015).

In contrast to the scarcity of domain-specific predictors acquired prior to formal schooling, there are a number of studies suggesting that children born very preterm demonstrate a poorer school performance in math than their peers (Aarnoudse-Moens et al., 2011; Hagen et al., 2006; Johnson et al., 2011). Overall, math disabilities at all the measured school ages appear to be more severe than reading disabilities in very preterm children (Aarnoudse-Moens, Smidts, Oosterlaan, Duivenvoorden, \& Weisglas-Kuperus, 2009; Aarnoudse-Moens, Weisglas-Kuperus, van Goudoever, \& Oosterlaan, 2009; Aarnoudse-Moens et al., 2011; Anderson \& Doyle, 2003; McGrath \& Sullivan, 2002; Rickards et al., 2001; Saigal et al., 2000). There is also evidence that among preterm born children, lower birth weight influences math scores with ELBW children being outperformed by their birth weight 1001-1500 g peers (Espy, Fang, Charak, Minich, \& Taylor, 2009; Hagen et al., 2006).

\subsection{School readiness skills and neonatal brain pathology}

In their recent meta-analysis, Linsell et al. (2015) concluded that the role of neonatal brain injury as a prognostic factor for language impairment is equivocal. There is some evidence that among preterm born seven-year-olds, neonatal brain injury is related with processing speed (Murray et al., 2014) as well as with spatial memory and list learning (Omizzolo et al., 2014). Setänen et al. (2013) found that the severity of neonatal brain pathologies was strongly associated with full scale IQ among preterm born five-year-olds. However, gross measures such as these are conceptually remote to foundational reading and math skills. The only study directly bearing on this issue appears to be that of Harmon et al. (2015). The authors found that at six years of age, extremely preterm born children with either transient or persistent neonatal abnormalities showed an impairment in letter and 
word identification, spelling and applied math problems, compared to peers with a normal neurological assessment. It should be noted that Harmon and associates did not deploy a full-term control group.

\subsection{The present study}

The present study is part of a longitudinal follow-up of very preterm Finnish children and their healthy FT peers. The defined birth weight for the very preterm was $1500 \mathrm{~g}$ or below or a gestational age of $<32$ weeks, and the FT children's birth weight was appropriate for their gestational age. Their pre-reading skills were studied at five years of age (Munck et al., 2012). It was found that very preterm children were outperformed by their FT peers in letter knowledge, phonological processing, rapid naming of overlearned items, and performance IQ but not in verbal IQ. However, the differences were not impressive given the effect sizes (Cohen's d) ranging from 0.33 (rapid naming) to 0.51 (phonological processing). Moreover, the differences were not significant after controlling for FSIQ. The authors concluded that about $75 \%$ of the very preterm children performed within the normal range. However, this also means that they were overrepresented in the low-performing group defined as being at least one standard deviation below the mean in each pre-reading skill.

The aim of the present study was to compare reading and math skills of preterm and full-term children at the beginning of grade 1 . The following hypotheses were tested.

(a) At the group level, full-term born first-graders outperform their preterm born peers in foundational skills in reading and math. The different is accentuated with extremely low birth weight children.

(b) There is a considerable overlap between the groups in reading whereas the difference in math skills is larger.

(c) Neonatal brain pathologies have a detrimental effect on school readiness skills in reading and math.

\section{Method}

\subsection{Participants}

This study is part of a multidisciplinary project following very preterm infants from infancy to school age. The very preterm group included all very low or extremely low birth weight (VLBW, $\leq 1500 \mathrm{~g}$ ) infants born between 2001 and 2006, and all infants born below 32 gestational weeks (VLGA) between 2004 and 2006. Attrition (26.7\%) is described in detail by Setänen et al. (2013), the major cause being early death (14\%). Children with disabilities were included except for four with genetic syndromes. All the children in the very preterm group were born at Turku University Hospital. The control group included randomly selected healthy FT peers with a birth weight appropriate for their gestational age at or later than 37 weeks. FT children were born at the same hospital between 2001 and 2004. Both a birth weight below $1500 \mathrm{~g}$ and a low gestational age (below 32 weeks) have been shown to be risks for later development (e.g. Anderson, 2014; Guellec et al., 2016). In this paper, these inclusion criteria are referred to as VLGA/VLBW. The limits are based on the World Health Organization definitions of very preterm birth ( $<32$ weeks of gestation) and very low birth weight $<1500 \mathrm{~g}$ (World Health Organization - International Classification of Diseases, National Institute for Health and Welfare - Medical Birth Register). The 369 participants included 194 VLGA/VLBW children (43\% girls) and 175 term children (52\% girls). The birth weight of the VLGA/ VLBW infants varied from 400 to $2120 \mathrm{~g}(\mathrm{M}=1124 \mathrm{~g}, \mathrm{SD}=326 \mathrm{~g})$ and the gestational age from 23 to 35 weeks ( $M=29.0$ weeks, $\mathrm{SD}=$ 2.7 weeks). A total of 154 infants were born below $1500 \mathrm{~g}$ birth weight and below 32 weeks of gestation, 15 infants met only the gestational age
Table 1

Infant characteristics and mother's education of preterm infants (VLGA/VLBW) and fullterm infants (FT).

\begin{tabular}{|c|c|c|}
\hline & VLGA/VLBW $(n=194)$ & $\mathrm{FT}(n=175)$ \\
\hline Prenatal corticosteroids & 169 & \\
\hline Multiple birth & 59 & 1 \\
\hline \multicolumn{3}{|l|}{ Birth weight (g) } \\
\hline \multirow[t]{2}{*}{ Mean (SD) (min, max) } & $1027(302)$ & $3673(442)$ \\
\hline & 384,1730 & 2570,4980 \\
\hline Small for gestational age SGA & 66 & \\
\hline \multicolumn{3}{|l|}{ Gestational age (weeks) } \\
\hline \multirow[t]{2}{*}{ Mean (SD) (min, max) } & $28.5(2.8)$ & $39.7(1.2)$ \\
\hline & $(23,35)$ & $(37,42)$ \\
\hline Male & 111 & 84 \\
\hline Apgar $<6$ at 5 min & 59 & \\
\hline \multicolumn{3}{|l|}{ Days on ventilator } \\
\hline Mean (SD) (min, max) & $9.3(15.9)(0,143)$ & \\
\hline Postnatal steroids & 28 & \\
\hline Chronic lung disease, CLD & 25 & \\
\hline Ductal ligation & 24 & \\
\hline Sepsis or meningitis & 38 & \\
\hline Intestinal perforation (NEC incl.) & 11 & \\
\hline Retinopathy of prematurity & 7 & \\
\hline Hydrocephalus with a shunt & 5 & \\
\hline Days in hospital mean (SD) & $50.3(36.4)$ & \\
\hline$(\min , \max )$ & $(0,183)$ & \\
\hline \multicolumn{3}{|l|}{ Maternal education } \\
\hline Nine years or less & 19 & 9 \\
\hline Over nine years $\rightarrow 12$ years & 46 & 62 \\
\hline$>12$ years & 128 & 104 \\
\hline \multicolumn{3}{|l|}{ Paternal education } \\
\hline Nine years or less & 16 & 14 \\
\hline Over nine years $\rightarrow 12$ years & 110 & 74 \\
\hline$>12$ years & 68 & 86 \\
\hline
\end{tabular}

criterion and 25 infants met only the birth weight inclusion criterion. Additional participant characteristics are given in Table 1.

\subsection{Study design and procedure}

In addition to school readiness measures, previously collected data were used. Cranial ultrasound examinations were conducted on all the infants born preterm at 3 to 5 days of age, at 7 to 10 days of age, at one month, and each month thereafter until discharge from the hospital. Brain magnetic resonance imaging was done for 190 infants at term on the same day as the ultrasound examination. For one infant there were five days between the examinations. (For a detailed description of the examinations and classification of the degree of brain pathology, see Maunu et al., 2006, pp. 58-59.) VLGA/VLBW children were categorized into groups according to the findings of their pathological brain imaging: 1) normal findings, 2) minor findings with no shown significance, and 3) major pathologies. Sixty percent of VLGA/VLBW children had no abnormal findings, $14 \%$ had minor findings, and $26 \%$ had major pathologies. A more detailed category content description is given in Appendix 2 (see also Setänen et al., 2013).

The mothers' level of education at the time of birth did not differ between the VLGA/VLBW group and FT group while fathers with a higher education were overrepresented in the FT group (Table 1). The home language of the participating families was Finnish. We lack precise data on preschool exposure in our sample. However, virtually every Finnish child went to kindergarten on a voluntary basis between the years 2007-2013, when the present data were collected (e.g. Torppa et al., 2016).

\subsubsection{Cognitive level}

A short version of a Finnish translation of Wechsler Primary and Preschool Scales of Intelligence-Revised (WPPSI-R) was used when the participants were 60 to 62 months old. The three verbal subtests and 
their age-appropriate reliabilities as given by the test manual were Information $(\alpha=0.71)$, Sentences $(\alpha=0.72)$ and Arithmetic $(\alpha=$ $0.84)$. The performance subtests were Block Design $(\alpha=77)$, geometric design $(\alpha=0.68)$ and Picture Completion $(\alpha=0.68)$. The FSIQ reliability is reported $\alpha=0.85$. Subtest selection was based on the highest correlations with FSIQ.

School readiness was examined at kindergartens, schools, and children's homes during a six-week period in August-September during the school entrance year. In Finland, children begin primary school in the year when they turn 7 years of age. The average age of the participants was 86.2 months $(\mathrm{SD}=3.4)$. The 45 -minutelong one-to-one assessments took place in a quiet room. Five trained testers performed a video-recorded pilot session before the data collection. These were used for harmonizing practices among the testers.

The PIPARI (Development and Functioning in Very Low Birth Weight Infants from Infancy to School Age) Study protocol has been approved by the Ethics Review Committee of the Hospital District of South-West Finland. All participating families gave their informed consent.

\subsection{Reading measures}

\subsubsection{Letter knowledge}

The children were asked to name 29 uppercase letters arranged in a random order in three rows and shown one row at a time (Lerkkanen, Poikkeus, \& Ketonen, 2006). One point was given for each correct response. Cronbach's alpha for the task was 0.95.

\subsubsection{Phoneme blending}

Three- to seven-letter words were presented to a group of children phoneme by phoneme (Poskiparta, 1995). The following instruction was given by the researcher: "You have in front of you a sheet of paper with ten tasks. Each task has a number. Each task also has four alternative pictures. First, I always say the number. Then I say a word but I say it one sound at a time. Your task is to guess which word I mean. Listen carefully because I will say the sounds only once." Children were asked to mark the answer with a cross on the picture matching the word. The test consisted of one practice trial and nine test trials. Cronbach's alpha for the test was 0.73 .

Rapid Automatized Naming (RAN) was assessed using the standard procedure (Denckla \& Rudel, 1976) with the following instruction: "Here you see many pictures of things. Tell me what this is (child names five pictures making a row). You should name all these pictures in this order. You should begin from this row and then move right away to the following row and then to the following. You do not stop stop until here. You can point to the row with your finger. Try to be fast and accurate. If you say something wrong, then correct it." The matrix consisted of 12 rows with five pictures of objects in each. The naming time in seconds for the total matrix was used as the measure.

Word reading was assessed using a wordlist consisting of two-syllabic ( 7 words), three-syllabic ( 2 words) and five-syllabic ( 1 word) words (Lerkkanen et al., 2006). The test was discontinued after three successive failures. The raw sum score of the correct items was used. Cronbach's alpha was 0.97 .

The reading accuracy and fluency task (Häyrinen, Serenius-Sirve, \& Korkman, 1999) consisted of 90 words on a sheet of paper arranged in three columns in an ascending order of difficulty. The child read as many words as possible during $45 \mathrm{~s}$. Cronbach's alpha, computed for the first 55 words, was 0.97 .

Learning to read in a transparent orthography such as Finnish occurs within four to six months from the beginning of grade 1 . Therefore, the gray zone from a non-reader to a reader is fairly brief and difficult to define quantitatively. This is so because the change from insecure and flawed reading attempts ("emerging reading") to accurate decoding usually takes place within one to two weeks (Silvén, Poskiparta, Niemi, \& Voeten, 2007). If continuous data on reading ability are used, the distribution will be strongly bimodal with the phase of insecure reading being represented by relatively few children. In addition, about one third of Finnish school beginners can already read before beginning school (Niemi et al., 2011). A relevant question thus is whether the possible overall difference between VLGA/VLBW/and FT groups holds true across subgroups of non-readers and precocious readers. To qualify as a reader, the child must be able to decode a letter string with an accuracy of at least $90 \%$. We defined non-readers as those school beginners who read either insecurely or not at all, that is, scoring from 0 to 8 on the reading test consisting of 10 isolated words (Lerkkanen et al., 2006).

\subsection{Math measures}

Naming of numbers consisted of 12 different numbers, beginning with 9 and 15 and ending with 15,402 and 627,003. Very easy and difficult items were included to avoid floor and ceiling effects. The numbers were presented one at a time and there was no time limit. The test was discontinued after two successive failures. Cronbach's alpha was 0.82 .

Number counting skills were assessed with the following seven subtasks: 1) counting forwards from one until given permission to stop at 51,2 ) counting from 6 to 13,3 ) counting from 18 to 25,4 ) counting backwards from 12, 5) counting backwards from 23, 6) counting backwards from 33, and in task 7) participants were asked to count 5 steps backward from 23. The total score was based on the number of correct items ( $\max =14$ ). Two points were given in every subtask if the participant made no errors. One point was given if the performance contained one or two errors. Cronbach's alpha was 0.82 .

Arithmetic skills were assessed with a set of addition and subtraction tasks (Aunola \& Räsänen, 2006). Children were asked to do as many of these as they could in $3 \mathrm{~min}$. The test is difficult for school beginners with only four tasks being single-digit additions or subtractions and because most items presuppose/going beyond number 10 . One point was given for each correct answer. The total maximum score for the arithmetic test was 28 points. Cronbach's alpha was 0.85 , and computed on the basis of items that showed variance.

\subsection{Statistical analysis}

Because of clear departures from normal distribution, statistical analysis was done using non-parametric tests and generalized linear models. The proportions of readers were compared between VLGA/ VLBW and FT groups using the chi-square test. The chi square test for trend was used to compare parental education levels between the groups. Univariate associations between continuous dependent variables and dichotomous explanatory variables were studied using the Mann-Whitney $U$ test. Univariate associations between continuous dependent variables and brain pathology were studied using the Kruskal-Wallis test. Univariate associations between two continuous variables were studied using Spearman's correlation coefficient.

Dependent variables were further compared between VLGA/VLBW and FT children controlling for FSIQ using generalized linear models. More specifically, dependent variables counting, naming numbers, and rapid naming scores were analyzed using a normal distribution. Skewed scores for dependent variables, arithmetic ability, reading fluency, phoneme blending, and letter knowledge were analyzed using a negative binomial distribution. Prior to the latter analysis, variables with a ceiling effect (letter knowledge and phoneme blending) were reflected by subtracting the actual value from the maximum value. Because clinical problems associated with preterm birth and underweight are different, we calculated individual birth weight $z$-scores that correspond with the age and gender adjusted standard deviation scores according to Finnish 
Growth references between 24 and 40 weeks of gestational age. Generalized linear models were used to study the association between the birth weight $\mathrm{z}$ score and dependent variables.

Statistical analysis was done using SAS for Windows version 9.3. $p$ Values below 0.05 were considered statistically significant.

\section{Results}

Hypothesis 1. Do full-term born first-graders outperform their preterm born peers in reading and math? Is the different is accentuated with extremely low birth weight children?

Table 2 shows that all differences between VLGA/VLBW and FT groups were significant, with the effect sizes (Cohen's d) ranging from small to medium. Of reading-related variables, only RAN remained significant when the effect of FSIQ was controlled for, $\mathrm{F}(1)=5.0, p=$ 0.026 . The math data displayed a different pattern showing a highly significant FT group superiority with a medium strong effect size for each skill. It is noteworthy that the significant group differences were sustained for all three math skills even when the FSIQ was controlled for: counting, $\mathrm{F}(1)=7.86, p=0.005$; naming numbers, $\mathrm{F}(1)=5.95$, $p=0.015$; and arithmetic, $\mathrm{F}(1)=11.01, p=0.001$.

The second question related to Hypothesis 1 was whether there is a difference in performance between children with a birth weight of either $<1000 \mathrm{~g}$ or $>1000 \mathrm{~g}$. Table 3 shows that of the 11 measures, phoneme blending, rapid naming and arithmetic showed a significant difference in favor of children with a birth weight of $>1000 \mathrm{~g}$. An additional analysis was done on the basis of the birth weight $z$ score, used as an estimate of antenatal growth. This score was associated with rapid naming in the univariate analysis $(p=0.02)$ so that an increase of one SD in birth weight decreased the time for naming by $2.6 \mathrm{~s}$. No other differences were related to the $\mathrm{z}$ score of birth weight.

Hypothesis 2. Do performances of VLBW/VLGA and FT groups show an overlap in reading but not in math?

Table 2

Means, standard deviations, medians, Mann-Whitney $U$ test results, and effect sizes (Cohen's d) for VLGA/VLBW and FT groups.

\begin{tabular}{|c|c|c|c|c|c|c|c|c|}
\hline & Group & $n$ & M & SD & Md & Range & $p$ & d \\
\hline \multirow{2}{*}{$\begin{array}{l}\text { Letter naming } \\
(\max =29)\end{array}$} & VLGA/BW & 194 & 23.4 & 7.0 & 26.0 & $0-29$ & \multirow[t]{2}{*}{$<0.05$} & \multirow[t]{2}{*}{0.27} \\
\hline & FT & 173 & 25.1 & 5.4 & 27.0 & $5-29$ & & \\
\hline \multirow{2}{*}{$\begin{array}{l}\text { Phoneme } \\
\text { blending }\end{array}$} & VLGA/BW & 194 & 6.8 & 2.1 & 7.0 & $1-9$ & \multirow[t]{2}{*}{$<0.001$} & \multirow[t]{2}{*}{0.37} \\
\hline & FT & 173 & 7.5 & 1.7 & 8.0 & $2-9$ & & \\
\hline \multirow{2}{*}{$\begin{array}{l}\text { Rapid serial } \\
\text { naming, total } \\
\text { time, s }\end{array}$} & VLGA/BW & 191 & 76.5 & 21.3 & 72.0 & $37-163$ & \multirow[t]{2}{*}{$<0.001$} & \multirow[t]{2}{*}{0.50} \\
\hline & FT & 173 & 66.9 & 17.0 & 63.0 & $31-142$ & & \\
\hline \multirow{2}{*}{$\begin{array}{l}\text { Reading of words } \\
(\max =10)\end{array}$} & VLGA/BW & 194 & 4.3 & 4.3 & 2.0 & $0-10$ & \multirow[t]{2}{*}{$<0.001$} & \multirow[t]{2}{*}{0.3} \\
\hline & FT & 173 & 5.8 & 4.2 & 8.0 & $0-10$ & & \\
\hline \multirow{2}{*}{$\begin{array}{l}\text { Reading of word } \\
\text { list, time } \\
\text { limited task } \\
(\max =90)\end{array}$} & VLGA/BW & 181 & 7.5 & 11.1 & 1.0 & $0-48$ & \multirow[t]{2}{*}{$<0.001$} & \multirow[t]{2}{*}{0.34} \\
\hline & FT & 173 & 11.8 & 14.2 & 5.0 & $0-54$ & & \\
\hline \multirow{2}{*}{$\begin{array}{l}\text { Naming of } \\
\text { numbers } \\
(\max =12)\end{array}$} & VLGA/BW & 193 & 4.4 & 2.6 & 5.0 & $0-12$ & \multirow[t]{2}{*}{$<0.001$} & \multirow[t]{2}{*}{0.56} \\
\hline & FT & 173 & 5.9 & 2.5 & 6.0 & $0-12$ & & \\
\hline \multirow{2}{*}{$\begin{array}{l}\text { Counting skills } \\
\quad(\max =14)\end{array}$} & VLGA/BW & 193 & 6.3 & 3.8 & 6.0 & $0-14$ & \multirow[t]{2}{*}{$<0.001$} & \multirow[t]{2}{*}{0.60} \\
\hline & $\mathrm{FT}$ & 173 & 8.5 & 3.7 & 9.0 & $0-14$ & & \\
\hline \multirow{2}{*}{$\begin{array}{l}\text { Arithmetic tasks } \\
\quad(\max =28)\end{array}$} & VLGA/BW & 193 & 2.1 & 1.9 & 2.0 & $0-16$ & \multirow[t]{2}{*}{$<0.001$} & \multirow[t]{2}{*}{0.64} \\
\hline & FT & 173 & 3.5 & 2.5 & 3.0 & $0-12$ & & \\
\hline \multirow[t]{2}{*}{ Full-scale $\mathrm{IQ}^{\mathrm{a}}$} & VLGA/BW & 172 & 100.9 & 17.4 & 103.5 & $39-140$ & \multirow[t]{2}{*}{$<0.001$} & \multirow[t]{2}{*}{0.72} \\
\hline & FT & 161 & 112.5 & 14.1 & 112.0 & $75-149$ & & \\
\hline \multirow[t]{2}{*}{ Verbal IQ $^{\mathrm{a}}$} & VLGA/BW & 177 & 103.2 & 16.2 & 112.0 & $39-135$ & \multirow[t]{2}{*}{$<0.001$} & \multirow[t]{2}{*}{0.36} \\
\hline & FT & 161 & 108.7 & 13.5 & 110.0 & $65-142$ & & \\
\hline \multirow[t]{2}{*}{ Performance IQ ${ }^{\mathrm{a}}$} & VLGA/BW & 175 & 98.0 & 17.6 & 100.0 & 39-139 & \multirow[t]{2}{*}{$<0.001$} & \multirow[t]{2}{*}{0.87} \\
\hline & FT & 164 & 111.5 & 13.3 & 111.0 & $81-142$ & & \\
\hline
\end{tabular}

a FSIQ VIQ and PIQ were measured at the age of 60.6 months (SD 0.53). All other tests at the age of 86.2 months (SD 3.4).
Table 3

Means, standard deviations, medians, ranges, Kruskal-Wallis test results, and effect sizes (Cohen's d) for a birth weight of $>1000 \mathrm{~g}$ and ELBW ( $\leq 1000 \mathrm{~g}$ ) groups.

\begin{tabular}{|c|c|c|c|c|c|c|c|c|}
\hline & Group & $n$ & M & SD & Md & Range & $p$ & d \\
\hline \multirow{2}{*}{$\begin{array}{l}\text { Letter naming } \\
(\max =29)\end{array}$} & $\mathrm{BW}>1000$ & 118 & 23.6 & 6.9 & 26.5 & $2-29$ & \multirow[t]{2}{*}{$>0.05$} & \multirow[t]{2}{*}{0.09} \\
\hline & ELBW & 76 & 23.0 & 7.3 & 25.0 & $0-29$ & & \\
\hline \multirow{2}{*}{$\begin{array}{l}\text { Phoneme } \\
\text { blending } \\
(\max =9)\end{array}$} & $\mathrm{BW}>1000$ & 118 & 7.1 & 2.0 & 8.0 & $2-9$ & \multirow[t]{2}{*}{$<0.01$} & \multirow[t]{2}{*}{0.38} \\
\hline & ELBW & 76 & 6.3 & 2.2 & 7.0 & $1-9$ & & \\
\hline \multirow{2}{*}{$\begin{array}{l}\text { Rapid serial } \\
\text { naming, } \\
\text { total time, s }\end{array}$} & $\mathrm{BW}>1000$ & 117 & 72.3 & 17.8 & 69.0 & $35-156$ & \multirow[t]{2}{*}{$<0.01$} & \multirow[t]{2}{*}{-0.45} \\
\hline & ELBW & 75 & 82.1 & 26.1 & 76.0 & $0-163$ & & \\
\hline \multirow{2}{*}{$\begin{array}{l}\text { Reading of } \\
\text { words } \\
(\max =10)\end{array}$} & $\mathrm{BW}>1000$ & 118 & 4.6 & 4.3 & 4.50 & $0-10$ & \multirow[t]{2}{*}{$>0.05$} & \multirow[t]{2}{*}{0.18} \\
\hline & ELBW & 76 & 3.8 & 4.2 & 1.50 & $0-10$ & & \\
\hline \multirow{2}{*}{$\begin{array}{l}\text { Reading of } \\
\text { word list, } \\
\text { time limited } \\
(\max =90)\end{array}$} & $\mathrm{BW}>1000$ & 111 & 7.1 & 10.4 & 1.0 & $0-48$ & \multirow[t]{2}{*}{$>0.05$} & \multirow[t]{2}{*}{-0.09} \\
\hline & ELBW & 70 & 8.1 & 12.0 & 1.0 & $0-47$ & & \\
\hline \multirow{2}{*}{$\begin{array}{l}\text { Naming of } \\
\text { numbers } \\
(\max =12)\end{array}$} & $\mathrm{BW}>1000$ & 117 & 4.7 & 2.5 & 5.0 & $0-12$ & \multirow[t]{2}{*}{$>0.05$} & \multirow[t]{2}{*}{0.20} \\
\hline & ELBW & 76 & 4.1 & 2.7 & 5.0 & $0-11$ & & \\
\hline \multirow{2}{*}{$\begin{array}{r}\text { Counting skills } \\
(\max =14)\end{array}$} & $\mathrm{BW}>1000$ & 117 & 6.7 & 3.6 & 7.0 & $0-14$ & \multirow[t]{2}{*}{0.053} & \multirow[t]{2}{*}{0.28} \\
\hline & ELBW & 76 & 5.6 & 4.1 & 5.5 & $0-14$ & & \\
\hline \multirow{2}{*}{$\begin{array}{l}\text { Arithmetic } \\
\text { tasks } \\
(\max =28)\end{array}$} & $\mathrm{BW}>1000$ & 117 & 2.3 & 2.0 & 2.0 & $0-16$ & \multirow[t]{2}{*}{$<0.05$} & \multirow[t]{2}{*}{0.28} \\
\hline & ELBW & 76 & 1.8 & 1.6 & 2.0 & $0-6$ & & \\
\hline \multirow[t]{2}{*}{ Full-scale IQ ${ }^{\mathrm{a}}$} & $\mathrm{BW}>1000$ & 107 & 101.3 & 16.4 & 101.0 & $39-140$ & \multirow[t]{2}{*}{$>0.05$} & \multirow[t]{2}{*}{0.05} \\
\hline & ELBW & 65 & 100.4 & 19.1 & 104.0 & $42-133$ & & \\
\hline \multirow[t]{2}{*}{ Verbal IQ ${ }^{\mathrm{a}}$} & $\mathrm{BW}>1000$ & 110 & 104.4 & 14.5 & 107.0 & $58-135$ & \multirow[t]{2}{*}{$>0.38$} & \multirow[t]{2}{*}{0.20} \\
\hline & ELBW & 67 & 101.2 & 18.7 & 102.0 & $39-130$ & & \\
\hline \multirow{2}{*}{$\begin{array}{l}\text { Performance } \\
\mathrm{IQ}^{\mathrm{a}}\end{array}$} & $\mathrm{BW}>1000$ & 107 & 98.3 & 16.9 & 100.0 & $43-139$ & \multirow{2}{*}{$>0.05$} & \multirow[t]{2}{*}{0.04} \\
\hline & ELBW & 68 & 97.6 & 18.8 & 99.0 & $39-130$ & & \\
\hline
\end{tabular}

a FSIQ VIQ and PIQ were measured at the age of 60.6 months (SD 0.53). All other tests at the age of 86.2 months (SD 3.4).

Group differences in math performance were all sustained when FSIQ was used as a covariate whereas among 8 reading-related measures only the RAN difference was sustained. The effect sizes (Table 2) further suggest that the superiority of the FT group is more robust in math-related tasks.

Finnish children enter grade 1 when they turn seven years old. Partly because of this and particularly because of the grapheme-to-phoneme regularity of the Finnish language, about $35 \%$ can already read (e.g. Niemi et al., 2011). In the present samples, 55 (28.4\%) VLBW/VLGA children were readers and 139 (71.6\%) were not. For FT children the figures were 77 (44.5\%) and 96 (55.5\%) respectively. The frequency distributions differed significantly (Pearson $\chi^{2}=10.40, \mathrm{df}=1, p<0.01$ ), with readers being overrepresented among the FT children. Because scores for pre-reading skills i.e. phoneme blending and letter naming, approached the ceiling the maximum, we conducted an additional analysis separately for readers and non-readers. Table 4 shows that a statistically significant difference between VLGA/VLBW and FT children emerged only in rapid automatized naming and in both for readers and non-readers. Moreover, when the salient difference in FSIQ was controlled for, the difference was only sustained between VLGA/VLBW and FT readers, $\mathrm{F}(1)=4.21, p=0.026$. As already noted, the math data suggest a uniform significant FT group superiority with a medium strong effect size for each skill (see Table 2). When a comparison was made between VLBW/VLGA and FT readers, the latter were superior both in counting skills, $\mathrm{F}(1)=8.44, p=0.004$ and arithmetic, $\mathrm{F}(1)=$ $8.48, p=0.004$. This indicates that the weaker math profile of VLGA/ VLBW students intersects the entire group that is, also the precocious readers.

Hypothesis 3. Neonatal brain pathologies have a detrimental effect on school readiness skills in reading and math.

Comparison of the brain pathology groups among VLGA/VLBW children is given in Table 5. Three of the eight skills showed a significant 
Table 4

Means, standard deviations, and effect sizes (Cohen's d) of reading-related skills for non-reading and reading children at school entry.

\begin{tabular}{|c|c|c|c|c|c|c|}
\hline & Non-readers & & & Readers & & \\
\hline Test & VLGA/BW & FT & d & VLGA/BW & FT & d \\
\hline Phoneme blending $\max =9$ & $6.2(2.1)^{\dagger}$ & $6.7(1.7)$ & 0.26 & $8.4(1.0)$ & $8.5(1.0)$ & 0.18 \\
\hline Letter naming $\max =29$ & $21.7(7.6)$ & $22.8(6.3)$ & 0.16 & $27.6(1.6)$ & $27.9(1.2)$ & 0.19 \\
\hline Rapid naming (s) & $80.1(22.5)^{* *}$ & $72.5(18.7)$ & -0.36 & $66.1(16.8)^{*}$ & $59.9(11.2)$ & -0.45 \\
\hline Reading fluency $\max =90$ & $1.8(4.0)^{\dagger}$ & $2.18(4.8)$ & 0.10 & $21.0(10.7)$ & $23.8(12.8)$ & 0.23 \\
\hline Full-scale IQ & $96.3(17.5)^{* * *}$ & $107.9(13.3)$ & 0.74 & $111.4(12.1)^{* * *}$ & $117.5(13.2)$ & 0.48 \\
\hline
\end{tabular}

$\uparrow p<0.10$ by Kruskal-Wallis test comparing the group means within a category.

* $p<0.05$ by Kruskal-Wallis test comparing the group means within a category.

** $p<0.01$ by Kruskal-Wallis test comparing the group means within a category.

*** $p<0.001$ by Kruskal-Wallis test comparing the group means within a category.

group difference pointing to a relative disadvantage of VLGA/VLBW children with major brain pathology: phoneme blending, rapid serial naming, and counting. Nevertheless, the correlations between birth weight and these variables were uniformly low, varying from -0.19 to +0.17 (Table 6 ).

Because a number of comparisons were made, the probability increases that a correct null hypothesis is falsely rejected, that is, a difference between means is taken as real when it actually is not. Applying the Bonferroni correction would affect the significances in the following way. In Table 2, all but the effect of letter naming would be sustained. In Table 4, differences in rapid naming and FSIQ would be sustained for non-readers, as well as the difference in FSIQ for readers. For brain pathology subgroups (Table 5), only the difference in rapid naming would be barely sustained whereas all comparisons between ELBW and the groups with a birth weight $>1000 \mathrm{~g}$ would not be significant (Table 3).

\section{Discussion}

The present study compared the school readiness skills of sevenyear-old children with a very low gestational age and/or very low birth weight to those of a full term born control group. Maternal education was equally distributed between the groups. The tests targeted reading and math skills at the beginning of the first grade.

Table 5

VLGA/VLBW school beginners' reading and math performance as a function of severity of brain pathology (Kruskal-Wallis one-way analysis of variance).

\begin{tabular}{|c|c|c|c|c|c|c|c|}
\hline Measure & Status & $\mathrm{N}$ & M & SD & Md & $\chi^{2} \mathrm{df}=2$ & $p$ \\
\hline \multirow[t]{3}{*}{ Letter naming } & Normal & 111 & 24.11 & 6.34 & 27.0 & 2.04 & 0.361 \\
\hline & Minor & 27 & 24.71 & 4.57 & 26.5 & & \\
\hline & Major & 50 & 21.82 & 4.09 & 25.0 & & \\
\hline \multirow[t]{3}{*}{ Phoneme blending } & Normal & 111 & 7.13 & 1.98 & 8.0 & 7.73 & 0.021 \\
\hline & Minor & 27 & 7.00 & 1.78 & 7.0 & & \\
\hline & Major & 50 & 6.14 & 2.28 & 6.50 & & \\
\hline \multirow[t]{3}{*}{ Rapid serial naming } & Normal & 111 & 72.30 & 18.28 & 70.0 & 13.13 & 0.001 \\
\hline & Minor & 27 & 75.16 & 21.53 & 70.0 & & \\
\hline & Major & 50 & 86.15 & 24.72 & 80.0 & & \\
\hline \multirow[t]{3}{*}{ Reading of words } & Normal & 111 & 4.53 & 4.34 & 1.00 & 0.74 & 0.690 \\
\hline & Minor & 27 & 4.57 & 4.26 & 3.50 & & \\
\hline & Major & 50 & 3.86 & 4.09 & 2.00 & & \\
\hline \multirow{3}{*}{$\begin{array}{l}\text { Reading of word list } \\
\text { (time limited) }\end{array}$} & Normal & 111 & 7.80 & 10.95 & 1.00 & 0.356 & 0.837 \\
\hline & Minor & 27 & 6.65 & 9.67 & 1.50 & & \\
\hline & Major & 50 & 7.38 & 6.19 & 1.00 & & \\
\hline \multirow[t]{3}{*}{ Naming of numbers } & Normal & 111 & 4.52 & 2.67 & 5.00 & 0.807 & 0.668 \\
\hline & Minor & 27 & 5.04 & 2.19 & 5.00 & & \\
\hline & Major & 50 & 4.14 & 2.60 & 5.00 & & \\
\hline \multirow[t]{3}{*}{ Counting skills } & Normal & 111 & 6.75 & 3.61 & 6.50 & 7.271 & 0.026 \\
\hline & Minor & 27 & 6.96 & 3.64 & 8.00 & & \\
\hline & Major & 50 & 5.16 & 4.09 & 2.00 & & \\
\hline \multirow[t]{3}{*}{ Arithmetic } & Normal & 111 & 2.21 & 1.62 & 2.00 & 4.191 & 0.123 \\
\hline & Minor & 27 & 2.54 & 2.95 & 2.00 & & \\
\hline & Major & 50 & 1.68 & 1.54 & 1.00 & & \\
\hline
\end{tabular}

First, in accordance with previous research literature, we expected to find significantly lower performance in both reading and math skills among VLGA/VLBW children. This main hypothesis was confirmed. Our results further suggest that the difference in math profiles is more robust than that in reading skills. This pattern has also been reported previously (Aarnoudse-Moens, Smidst et al., 2009; Aarnoudse-Moens, Weisglas-Kuperus et al., 2009; Aarnoudse-Moens et al., 2011; Anderson \& Doyle, 2003; McGrath \& Sullivan, 2002; Rickards et al., 2001; Saigal et al., 2000). However, contrary to our hypothesis, the further comparison of ELBW children with VLGA/VLBW peers with birth weight above $1000 \mathrm{~g}$ gave mixed results with only three of the 11 measures showing a difference. This is in line with our finding that the gestational age and gender adjusted birth weight z-score was only associated with rapid naming ability but not with performance in detailed tests of school readiness skills.

Second, we predicted a qualification of the main difference between VLGA/VLBW children and FT peers so that performance profiles would overlap in reading but be more distinct in math. The results lend support to the hypothesis. While being significant beyond dispute, the absolute differences in reading were rather small indicating a substantial overlap, which was also reflected in the small to medium effect sizes. Moreover, an inspection of the reading data suggests that the average performance of VLGA/VLBW children is far from poor, and shows no sign of floor effects. Therefore, an overall difference can be misleading despite statistical significance. In fact, it appears that the group differences are accounted for by the significantly greater share of precocious readers among FT children. It is noteworthy, however, that the proportion of precocious readers in the VLGA/VLBW group is also in line with the average of 35\% found in a recent large-scale Finnish study (Niemi et al., 2011). Therefore, we examined the group differences among those VLGA/VLBW and FT children who read insecurely or not at all. An intriguing finding was that these two subgroups performed similarly in reading-related tasks, while there were robust differences in rapid naming and FSIQ. The independent predictive status of rapid naming and FSIQ is also highlighted by the finding that when the effects of FSIQ were controlled for, only those of rapid naming survived. In general, the results support the notion that VLGA/VLBW and FT children belong

Table 6

Spearman correlations between brain pathology ( $1=$ normal: $2=$ minor; $3=$ major $)$, birth weight $(\mathrm{g})$ and school readiness measures among VLGA/VLBW children.

\begin{tabular}{lcc}
\hline & Birth weight & Brain pathology \\
\hline Letter naming & 0.03 & -0.02 \\
Phoneme blending & 0.10 & -0.15 \\
Rapid naming & -0.14 & 0.17 \\
Reading of words & 0.01 & 0.01 \\
Reading of word list & -0.10 & 0.02 \\
Naming of numbers & 0.10 & -0.02 \\
Counting skills & 0.13 & -0.14 \\
Arithmetic & 0.15 & -0.09 \\
Full Scale IQ & 0.06 & -0.19 \\
\hline
\end{tabular}


to the same distribution in terms of reading acquisition. Differences in math profiles were sustained after the same post hoc controls and also among those VLGA/VLBW and FT children who could already read, thus highlighting the more robust nature of math difficulties.

Third, we expected that neonatal brain pathology has a detrimental effect on school readiness skills. In line with Murray et al. (2014), major brain pathology was associated with impaired processing speed that is, rapid naming ability. On the whole, however, our brain pathology results are inconclusive. Because the available evidence has so far been scarce, the topic warrants further study.

Our main result is that school readiness profiles of VLGA/VLBW and FT children are much more similar in reading than in math. At first glance, this outcome seems to warrant the conclusion that the group differences are domain specific rather than general. Learning to read is a markedly verbal feat whereas performance in math tasks employs more general problem solving abilities. Moreover, even our FT readers outperformed the VLGA/VLBW readers in both counting and arithmetic, indicating a fundamental difference between reading and math performance. Notwithstanding these differences, our data seem to speak in favor of the generality view on several accounts. First, even the highly significant overall group differences in reading were canceled when using the FSIQ as a covariate. This means that, among other things, the notoriously general FSIQ also measures such cognitive skills that are in use when the child learns to read. Second, in addition to being a potent predictor of reading ability, rapid naming has also proved to be resistant to statistical controls including different measures of IQ (Kirby, Georgiou, Martinussen, \& Parrila, 2010); this was also the case in the present study. It has additionally been shown that rapid naming is associated with developmental immaturity as well as a number of illnesses among very preterm children (Guarini et al., 2010). Moreover, it is suggested that rapid naming integrates object recognition and naming circuits in the left hemisphere (Lervåg \& Hulme, 2009), thus exploiting the processes relevant to reading at a general level. Rapid naming of objects and colors correlates with both reading and math measures among learning-disabled children (Donker, Kroesberger, Slot, Van Viersen, \& De Bree, 2016) and its predictive power in both skill domains is resistant to various cognitive control measures (Koponen, Salmi, Eklund, \& Aro, 2013). Third, there was also a robust interaction between verbal and performance IQ, indicating that VLGA/VLBW children were markedly inferior in the more general PIQ, thus resulting in a large difference in FSIQ. This imbalance corresponds with the scholastic results. While beginning reading is confined to the verbal domain and consists of word decoding in transparent orthographies such as Finnish, however, beginning math is closer to problem solving, and more related to but not covered by PIQ or FSIQ. Finally, major brain pathology at term age was particularly associated with an impaired naming speed at school entry.

\subsection{Limitations}

Based on the results, our main conclusion is that very preterm birth causes a delay in general cognitive development affecting school readiness skills particularly in math. However, this conclusion also leads to the major limitation of our study, that is, the lack of measures for executive processes. We had no direct measures of, for example, attention shifting, response inhibition, or working memory, which have been found to associate strongly with math difficulties in primary grades in an unselected sample (Toll, Van der Ven, Kroesbergen, \& Luit, 2011). VLBW children show a consistent relative impairment in executive functions both in preschool (Lowe et al., 2014) and primary grades (Aarnoudse-Moens, Smidst et al., 2009; Aarnoudse-Moens, Weisglas-Kuperus et al., 2009). Finally, executive functions have been found to predict math difficulties among preterm born students in a primary school even after controlling for IQ (Aarnoudse-Moens, Weisglas-Kuperus, Duivenvoorden, van Goudoever, \& Oosterlaan, 2013). While our three math measures had an adequate reliability, the arithmetic test chosen in view of a further follow-up of the same sample proved too difficult, resulting in a skewed distribution. Performing addition and subtraction tasks before they are formally taught is too challenging. Developmental literature suggests that more ageappropriate tests would have been counting with cardinality and conceptual subitizing (Nguyen et al., 2016), speeded numerosity and number comparison for quantity (Sasanguie, De Smedt, Defever, \& Reynvoet, 2012) as well as a number line estimation (Booth \& Siegler, 2008).

It has been suggested that the performance of small-for-gestationalage preterm children is poorer in cognitive tests compared to preterm children with normal intrauterine growth, even with a lower gestational age (Lundequist et al., 2015). However, in our study population, SGA status was not a risk factor for overall cognitive development at 5 years of age (Leppänen et al., 2014); although the neuropsychological profile of SGA infants born above 32 weeks of gestation showed some weaknesses (Lind et al., 2011). As SGA infants had been excluded from our FT control group this potentially improved the performance of the controls compared to an unselected normal population.

\section{Conclusions and need for future studies}

The reading difficulties of VLGA/VLBW school beginners are milder than their math difficulties and most first graders read as well as their FT peers. On the other hand, the first year in school establishes the basis for further scholastic development. It has been reported that 70\% of first graders who read poorly are struggling readers still in grade 8 (Landerl \& Wimmer, 2008). To our knowledge, no comparable longterm data on math difficulties are available but a similar trend would not be surprising. Inspection of VLBW literature reveals an increasing number of prediction studies and an almost total absence of intervention aiming at better school readiness skills or later scholastic achievement. Obviously, struggling preterm born children receive remedial instruction with other children in need (Litt et al., 2005). However, prediction studies do not lay the foundation for the targeted interventions they may need. We wish to cite researchers who have envisaged the problem clearly (Decker et al., 2013, p. 304): "However, it is likely the increased emphasis for assessments to inform intervention, rather than predicting achievement, will lead toward understanding individual differences by examining cognitive strengths and weaknesses rather than IQ."

\section{Conflict of interest statement}

The funding sources had no role in the study design, collection, analysis, or interpretation of the data, the writing of the article, or the decision to submit it for publication. The authors declare no financial interest, arrangement, or affiliation with a commercial organization that may have direct or indirect interest in the subject matter.

\section{Acknowledgements}

The PIPARI Study group: Mikael Ekblad, MD; Satu Ekblad, RN; Eeva Ekholm, MD, PhD; Pentti Kero, MD, PhD; Virva Saunavaara, MSc, PhD; Marika Leppänen, MD, PhD; Annika Lind, PhD; Hanna Manninen, MD; Jonna Maunu, MD, PhD; Anna Nyman, Psych.Lic.; Pertti Palo, MD, PhD; Riitta Parkkola, MD, PhD; Liisi Rautava, MD, PhD; Katriina Saarinen, Physiotherapist; Elina Savonlahti, MD; Sirkku Setänen, MD; Matti Sillanpää, MD, PhD; Suvi Stolt, PhD; Päivi Tuomikoski-Koiranen, RN; Timo Tuovinen, BA; Milla Ylijoki, MD, PhD; Tuula Äärimaa, MD, PhD.

This study was supported by grants from the Turku University Hospital EVO Funds (13630/2003-2017). 


\section{Appendix 1}

Summary of studies published 2006-2016 on reading and math skills of very preterm children, age range 5-15 years.

\begin{tabular}{|c|c|c|c|c|c|c|}
\hline $\begin{array}{l}\text { Authors, publication } \\
\text { year, country }\end{array}$ & $\begin{array}{l}\text { Number of } \\
\text { participants }\end{array}$ & $\begin{array}{l}\text { Inclusion } \\
\text { criteria/Mean birth } \\
\text { weight and } \\
\text { gestational age }\end{array}$ & Mean age & Main results regarding reading and math skills & Proposed causal influences & $\begin{array}{l}\text { Birthweight }>1000 \mathrm{~g} \text { vs. } \\
\text { ELBW }\end{array}$ \\
\hline $\begin{array}{l}\text { Aarnoudse-Moens et } \\
\text { al., } 2011 \\
\text { Netherlands }\end{array}$ & $\begin{array}{l}200 \text { very } \\
\text { preterm }+230 \\
\text { full-term } \\
\text { children }\end{array}$ & $<30$ weeks & $4-12$ years & $\begin{array}{l}\text { Very preterm children had lower IQ, poorer performance in } \\
\text { numerical reasoning skills and mathematics, but not in } \\
\text { early linguistics, reading comprehension and spelling. }\end{array}$ & & \\
\hline $\begin{array}{l}\text { Aarnoudse-Moens et } \\
\text { al., } 2013 \\
\text { Netherlands }\end{array}$ & $\begin{array}{l}200 \text { very } \\
\text { preterm }+230 \\
\text { full-term } \\
\text { children }\end{array}$ & $<30$ weeks & 8.2 years & $\begin{array}{l}\text { Very preterm children had lower IQ and poorer } \\
\text { performance on mathematical skills }\end{array}$ & IQ and executive function predicted mathematical skills. & \\
\hline $\begin{array}{l}\text { Dahl \& Kamper, } 2006 \\
\text { Denmark }\end{array}$ & $\begin{array}{l}60 \text { VLBW } \\
\text { children }+60 \\
\text { siblings }\end{array}$ & & & $\leq 1500 \mathrm{~g}, \leq 37$ weeks, & 13 years & $\begin{array}{l}\text { No difference in math and } \\
\text { reading performance } \\
\text { compared to siblings. }\end{array}$ \\
\hline $\begin{array}{l}\text { Espy et al., } 2009 \\
\text { United States }\end{array}$ & $\begin{array}{l}129 \text { VLBW }+69 \\
\text { NBW }\end{array}$ & $<1499$ g, preterm & $7-16$ years & & $\begin{array}{l}\text { Neonatal medical variables were more important predictors of } \\
\text { academic achievement than birth weight. }\end{array}$ & $\begin{array}{l}\text { Birth weight was a robust } \\
\text { predictor of math } \\
\text { achievement }\end{array}$ \\
\hline $\begin{array}{l}\text { Guarini et al., } 2010 . \\
\text { Italy }\end{array}$ & $\begin{array}{l}68 \text { preterm } \\
\text { children and } 26 \\
\text { full-term } \\
\text { children }\end{array}$ & $\begin{array}{l}1243 \mathrm{~g}, \\
30.44 \text { weeks }\end{array}$ & $8: 0$ years & $\begin{array}{l}\text { Preterm children had no general delay, but made more } \\
\text { errors in writing accuracy and were slower in reading. }\end{array}$ & & \\
\hline $\begin{array}{l}\text { Gäddlin, Finnström, } \\
\text { Samuelsson, } \\
\text { Wadsby, Wang, \& } \\
\text { Leijon, 2008 } \\
\text { Sweden }\end{array}$ & $\begin{array}{l}61 \text { VLBW and } 57 \\
\text { full-term } \\
\text { adolescents }\end{array}$ & Not specified & 15 years & $\begin{array}{l}\text { VLBW adolescents had lower general cognitive abilities, but } \\
\text { performed equally to controls on most reading tasks }\end{array}$ & $\begin{array}{l}\text { VLBW boys with MRI deviations had significantly lower PIQ and } \\
\text { FSIQ than VLBW boys without white matter damage. White } \\
\text { matter damage, IQ and reading skills were not significantly } \\
\text { correlated. Intraventricular haemorrhage and mechanical } \\
\text { ventilation were associated with IQ and reading skills. }\end{array}$ & \\
\hline $\begin{array}{l}\text { Hagen et al., } 2006 \\
\text { United States }\end{array}$ & $\begin{array}{l}253 \\
\text { VLBW }+234 \\
\text { classmates and } \\
\text { school district } \\
\text { data }\end{array}$ & $\leq 1500 \mathrm{~g}$ & 10.2 years & VLBW children had difficulties in math but not in reading & & $\begin{array}{l}\text { Birthweight was } \\
\text { associated with math } \\
\text { scores }\end{array}$ \\
\hline $\begin{array}{l}\text { Hutchinson, De Luca, } \\
\text { Doyle, Roberts,, \& } \\
\text { Anderson, } 2013 \\
\text { Australia }\end{array}$ & $\begin{array}{l}189 \\
\text { EP/ELWB }+193 \\
\text { FT }\end{array}$ & $\begin{array}{l}<1000 \mathrm{~g}, \\
<28 \text { weeks }\end{array}$ & 8 years & $\begin{array}{l}\text { Very preterm children had lower IQ and poorer reading, } \\
\text { spelling, and mathematics skills even after excluding } \\
\text { children with neurosensory impairment. }\end{array}$ & & $\begin{array}{l}\text { No differences between } \\
\text { smaller and larger } \\
\text { children. }\end{array}$ \\
\hline $\begin{array}{l}\text { Australla } \\
\text { Johnson, Hennessy, } \\
\text { Smith, Trikic, } \\
\text { Wolke, \& Marlow, } \\
2009 \\
\text { United Kingdom, } \\
\text { Ireland }\end{array}$ & 309 EP 153 FT & $<25$ weeks & $\begin{array}{l}\text { Median } \\
131 \text { months }\end{array}$ & $\begin{array}{l}\text { Extremely preterm children had significantly lower general } \\
\text { cognitive abilities and significantly lower math and reading } \\
\text { skills, with math being an area of special difficulty. }\end{array}$ & $\begin{array}{l}\text { After adjusting for general cognitive skills only math difficulties } \\
\text { remained. }\end{array}$ & \\
\hline $\begin{array}{l}\text { Johnson et al., } 2011 \\
\text { United Kingdom, } \\
\text { Ireland }\end{array}$ & $\begin{array}{l}219 \mathrm{EP} \text { and } 153 \\
\text { classmates }\end{array}$ & $740 \mathrm{~g},<26$ weeks & 10.9 years & $\begin{array}{l}\text { Extremely preterm children had significantly lower scores } \\
\text { in reading and mathematics as well as higher rates of } \\
\text { learning impairment than classmates. Greater problems in } \\
\text { mathematics than reading. }\end{array}$ & $\begin{array}{l}\text { IQ visuospatial skills, phonological processing, and executive } \\
\text { function at } 6 \text { years were associated with academic achievement } \\
\text { at } 11 \text { years }\end{array}$ & \\
\hline
\end{tabular}




\begin{tabular}{|c|c|c|c|c|c|c|}
\hline $\begin{array}{l}\text { Kiechl-Kohlendorfer, } \\
\text { Ralser, Peglow, } \\
\text { Pehboeck-Walsr, \& } \\
\text { Fussenegger, } 2013\end{array}$ & $\begin{array}{l}161 \text { very } \\
\text { preterm } \\
\text { children }\end{array}$ & $<32$ weeks & 5 years & $\begin{array}{l}\text { Eighteen percent of children had delayed cognitive } \\
\text { performance and } 20 \% \text { delayed numerical skills. }\end{array}$ & In half of the children delayed numerical skills were related to IQ. & $\begin{array}{l}\text { Pre- and perinatal factors } \\
\text { were predictive of } \\
\text { numerical skills. }\end{array}$ \\
\hline \multicolumn{7}{|l|}{ Austria } \\
\hline $\begin{array}{l}\text { Leijon, Ingemansson, } \\
\text { Nelson, Wadsby, \& } \\
\text { Samuelsson, } 2016\end{array}$ & $\begin{array}{l}51 \text { VLBW } \\
\text { children and } 51 \\
\text { controls }\end{array}$ & $\leq 1500 \mathrm{~g}$ & 7.8 years & $\begin{array}{l}\text { VLBW children had poorer performance on all reading and } \\
\text { cognitive function tasks and attention subscales, which in } \\
\text { turn were associated with phonological and orthographic }\end{array}$ & $\begin{array}{l}\text { Difficulties in vocabulary and attention explained many of the } \\
\text { poor reading results. }\end{array}$ & $\begin{array}{l}\text { Perinatal factors were not } \\
\text { associated with reading } \\
\text { skills. }\end{array}$ \\
\hline Litt et al., 2012 & 181 ELBW & $809 \mathrm{~g}, 26.4$ weeks & 14.8 years & ELBW adolescents had poorer performance on IQ & After controlling for IQ measures of executive function were & - \\
\hline United States & $\begin{array}{l}\text { adolescents and } \\
115 \text { controls }\end{array}$ & & & $\begin{array}{l}\text { executive function, reading and math measures, although } \\
\text { reading achievement fell in the normal average range. }\end{array}$ & related to math achievement but not to reading achievement. & \\
\hline $\begin{array}{l}\text { Munck, Niemi, } \\
\text { Väliaho, Lapinleimu, } \\
\text { Lehtonen, \& } \\
\text { Haataja, } 2012\end{array}$ & $\begin{array}{l}89 \text { VLBW } \\
\text { children and } \\
152 \text { controls }\end{array}$ & $1064 \mathrm{~g}, 28.7$ weeks & 5 years & $\begin{array}{l}\text { VLBW children had lower FSIQ and poorer prereading } \\
\text { skills. }\end{array}$ & $\begin{array}{l}\text { After controlling for IQ, prereading skills did not differ from skills } \\
\text { of the FT group }\end{array}$ & - \\
\hline \multicolumn{7}{|l|}{ Finland } \\
\hline $\begin{array}{l}\text { Pritchard et al., } 2014 \\
\text { New Zealand }\end{array}$ & $\begin{array}{l}110 \text { very } \\
\text { preterm }+113 \\
\text { full-term }\end{array}$ & $\leq 32$ weeks & $\begin{array}{l}4,6 \text {, and } \\
9 \text { years }\end{array}$ & $\begin{array}{l}\text { Very preterm children were more likely to have delays in } \\
\text { mathematical and reading skills. }\end{array}$ & & \\
\hline $\begin{array}{l}\text { Pritchard et al., } 2009 \\
\text { New Zealand }\end{array}$ & $\begin{array}{l}102 \text { very } \\
\text { preterm } \\
\text { children }+108 \\
\text { full-term } \\
\text { children }\end{array}$ & $\leq 33$ weeks & 6 years & $\begin{array}{l}\text { Very preterm children were more likely to have difficulties } \\
\text { in academic skills, especially in math. }\end{array}$ & & \\
\hline $\begin{array}{l}\text { Samuelsson et al., } \\
2006 \\
\text { Sweden }\end{array}$ & $\begin{array}{l}56 \text { VLBW }+52 \\
\text { NBW children }\end{array}$ & $1234 \mathrm{~g}, 31.2$ weeks & $\begin{array}{l}9 \text { and } \\
15 \text { years }\end{array}$ & $\begin{array}{l}\text { At } 9 \text { years of age VLBW children had lower IQ and worse } \\
\text { reading skill, but at } 15 \text { years of age most differences were } \\
\text { not significant. }\end{array}$ & $\begin{array}{l}\text { After controlling for IQ, word-recognition and reading } \\
\text { comprehension improved. Presence of cerebral insults was not } \\
\text { associated with reading skills. }\end{array}$ & - \\
\hline $\begin{array}{l}\text { Simms et al., } 2015 \\
\text { United Kingdom, } \\
\text { Ireland }\end{array}$ & $\begin{array}{l}115 \text { very } \\
\text { preterm }+77 \\
\text { full-term } \\
\text { children }\end{array}$ & $<32$ weeks & $8-10$ years & $\begin{array}{l}\text { Very preterm children had poorer performance than } \\
\text { controls on mathematical skills, working memory and } \\
\text { visuospatial skills, but not on processing speed or } \\
\text { inhibition. }\end{array}$ & $\begin{array}{l}\text { Difference in mathematical skills remained even after controlling } \\
\text { for nonverbal IQ. Working memory and visuospatial skills were } \\
\text { associated with mathematical skills. }\end{array}$ & \\
\hline $\begin{array}{l}\text { Simms, Gilmore, } \\
\text { Cragg, Marlow, } \\
\text { Wolke, \& Johnson, } \\
2013\end{array}$ & $\begin{array}{l}219 \text { extremely } \\
\text { preterm }+153 \\
\text { full-term } \\
\text { children }\end{array}$ & $<26$ weeks & 11 years & $\begin{array}{l}\text { Extremely preterm children had lower IQ poorer } \\
\text { visuospatial, executive function and sensorimotor skills } \\
\text { and performed worse on reading, mathematics, and } \\
\text { numerical representations. }\end{array}$ & $\begin{array}{l}\text { After controlling for IQ numerical representations were } \\
\text { associated with mathematical skills. }\end{array}$ & \\
\hline \multicolumn{7}{|l|}{$\begin{array}{l}\text { United Kingdom, } \\
\text { Ireland }\end{array}$} \\
\hline Taylor et al., 2011 & 148 & $<1000 \mathrm{~g}$ & 5.96 years & ELBW children had poorer skills than controls in spelling & Math difficulties were significant even after excluding children & Gestational \\
\hline United States & $\begin{array}{l}\mathrm{ELBW}+111 \\
\text { classmates }\end{array}$ & $<28$ weeks & & and applied mathematics. & with neurosensory deficits or low IQ. & $\begin{array}{l}\text { age }<25 \text { weeks was } \\
\text { associated with higher } \\
\text { rates of individual } \\
\text { education plans. }\end{array}$ \\
\hline $\begin{array}{l}\text { Wocadlo \& Rieger, } \\
2007 \\
\text { Australia }\end{array}$ & $\begin{array}{l}63 \text { very preterm } \\
\text { children }\end{array}$ & $<30$ weeks & 8 years & $\begin{array}{l}\text { Thirty-eight percent had difficulties in either reading, } \\
\text { spelling, or mathematics. Those with rapid naming deficits } \\
\text { were more likely to have comorbid difficulties in academic } \\
\text { skills. }\end{array}$ & & \\
\hline $\begin{array}{l}\text { Wolke et al., } 2008 \\
\text { United Kingdom, } \\
\text { Ireland }\end{array}$ & $\begin{array}{l}241 \text { extremely } \\
\text { preterm }+160 \\
\text { classmates }\end{array}$ & $<25$ weeks & 6 years & $\begin{array}{l}\text { Extremely preterm children were more likely to have } \\
\text { school difficulties, but these were not explained by general } \\
\text { cognitive abilities. }\end{array}$ & & \\
\hline
\end{tabular}




\section{Appendix 2}

Content description of brain pathology categories among VLGA/VLBW children based on MRI findings. (Maunu et al., 2006; after Setänen et al., 2013. Permission granted by Wiley.)

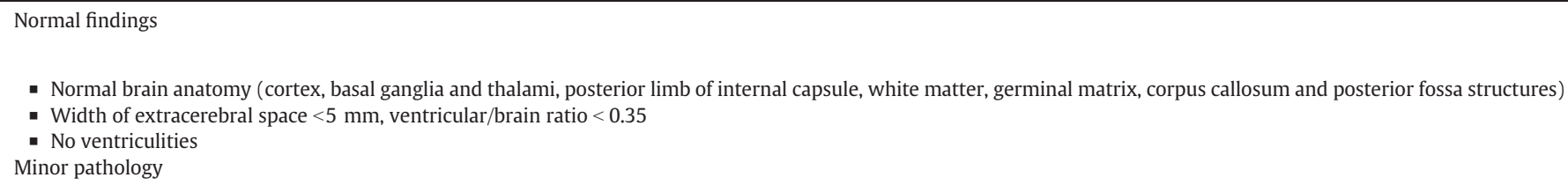

- Consequences of intraventricular haemorrhages grades 1 and 2

- Injury in cortex, basal ganglia, thalamus or internal capsule with injury of corpus callosum, cerebral injury, white matter injury

- Increased width of extracerebral space of $5 \mathrm{~mm}, \mathrm{~V} / \mathrm{B}$ ratio of 0.35

Major pathology

- Consequences of intraventricular haemorrhages grade 3 and 4

- Injury in cortex, basal ganglia, thalamus or internal capsule, with injury of corpus callosum, cerebral injury, white matter injury

- Increased width of extracerebral space $>5 \mathrm{~mm}$; V/B ratio $>0.35$, ventriculitis

- Other major pathology (infarcts)

\section{References}

Aarnoudse-Moens, C., Smidts, D., Oosterlaan, J., Duivenvoorden, H., \& Weisglas-Kuperus N. (2009). Executive function in very preterm children at early school age. Journal of Abnormal Child Psychology, 37, 981-993.

Aarnoudse-Moens, C. S. H., Weisglas-Kuperus, N., van Goudoever, J. B., \& Oosterlaan, J. (2009). Meta-analysis of neurobehavioral outcomes in very preterm and/or very low birth weight children. Pediatrics, 124, 717-728.

Aarnoudse-Moens, C. S., Oosterlaan, J., Duivenvoorden, H. J., van Goudoever, J. B., \& Weisglas-Kuperus, N. (2011). Development of preschool and academic skills in children born very preterm. Journal of Pediatrics, 158, 51-56.

Aarnoudse-Moens, C., Weisglas-Kuperus, N., Duivenvoorden, H., van Goudoever, J., \& Oosterlaan, J. (2013). Executive function and IQ predict mathematical and attention problems in very preterm children. PloS One, 8, e55994.

Anderson, P. J. (2014). Neuropsychological outcomes of children born very preterm. Seminars in Fetal \&' Neonatal Medicine, 19, 90-96.

Anderson, P., \& Doyle, L. W. (2003). Neurobehavioral outcomes of school-age children born extremely low birth weight or very preterm in the 1990s. Journal of the American Medical Association, 289, 3264-3272

Aunola, K., \& Räsänen, P. (2006). Kolmen minuutin aritmetiikan testi. Jyväskylän yliopisto: Julkaisematon testilomake. (Three minutes arithmetic test). University of Jyväskylä, Finland. (unpublished material).

Aunola, K., Leskinen, E., Lerkkanen, M. -K., \& Nurmi, J. -E. (2004). Developmental dynamics of math performance from preschool to grade 2. Journal of Educational Psychology 96, 699-713.

Aylward, G. P. (2002). Cognitive and neuropsychological outcomes: More than IQ scores. Mental Retardation and Developmental Disabilities Research Reviews, 8, 234-240.

Booth, J. L., \& Siegler, R. S. (2008). Numerical magnitude representations influence arithmetic learning. Child Development, 79, 1016-1031.

Breeman, L. D., Jaekel, J., Baumann, N., Bartmann, P., \& Wolke, D. (2015). Preterm cognitive function into adulthood. Pediatrics, 136, 415-423.

Cirino, P. T. (2011). The interrelationships of mathematical precursors in kindergarten Journal of Experimental Child Psychology, 108, 713-731.

Dahl, M., \& Kamper, J. (2006). Physical outcome and school performance of very-lowbirthweight infants treated with minimal handling and early nasal CPAP. Acto Paediatrica, 95, 1099-1103.

Decker, S., Hale, J., \& Flanagan, D. (2013). Professional practice issues in the assessment of cognitive functioning for educational application. Psychology in the Schools, 50 300-313.

Denckla, M. B., \& Rudel, R. G. (1976). Rapid “automatized” naming (r.a.n.): Dyslexia differentiated from other learning disabilities. Neuropsychologia, 14, 471-479.

Donker, M., Kroesbergenr, E., Slot, E., Van Viersen, S., \& De Bree, E. (2016). Alphanumeric and non-alphanumeric Rapid Automatized Naming in children with reading and/or spelling difficulties and mathematical difficulties. Learning and Individual Differences, $47,80-87$.

Espy, K. A., Fang, H., Charak, D., Minich, N., \& Taylor, G. H. (2009). Growth mixture modeling of academic achievement in children of varying birth weight risk. Neuropsychology, 23, 460-474

Feldman, H., Lee, E., Yeatman, J., \& Yeom, K. (2012). Language and reading skills in schoolaged children and adolescents born preterm are associated with white matter properties on diffusion tensor imaging. Neuropsychologia, 50, 3348-3362.

Gäddlin, P. D., Finnström, O., Samuelsson, S., Wadsby, M., Wang, C., \& Leijon, I. (2008). Academic achievement, behavioural outcomes and MRI findings at 15 years of age in very low birthweight children. Acta Paediatrica, 97, 1426-1432.
Gardella, B., Iacobone, A. D., Bogliolo, S., Musacchi, V., Orcesi, S., Tzialla, C., \& Spinillo, A. (2015). Obstrectic risk factors and time trends in neurodevelopmental outcome at 2 years in ver-low-birthweight infants: A single institution study. Developmental Medicine and Child Neurology, 57, 1035-1041.

Gray, S. C., Edwards, S. E., Schultz, B. D., \& Miranda, M. L. (2014). Assessing the impact of race, social factors and air pollution on birth outcomes: A population-based study. Environmental Health, 13, 1-8.

Guarini, A., Sansavini, A., Fabbri, C., Savini, S., Alessandroni, R., Faldella, G., \& KarmiloffSmith, A. (2010). Long-term effects of preterm birth on language and literacy at eight years. Journal of Child Language, 37, 865-885.

Guellec, I., Lapillonne, A., Marret, S., Picaud, J. C., Mitanchez, S., Charkaluk, M. L., ... EPIPAGE Study Group (2016). The Journal of Pediatrics, 175, 93-99.

Hagen, E. W., Palta, M., Albanese, A., \& Sadek-Bawawi, M. (2006). School achievement in a regional cohort children born very low birthweight. Journal of Developmental and Behavioral Pediatrics, 27, 112-120.

Harmon, H. M., Taylor, H. G., Minich, N., Wilson-Costello, D., \& Hack, M. (2015). Early school outcomes for extremely preterm infants with transient neurological abnormalities. Developmental Medicine and Child Neurology, 57, 865-871.

Häyrinen, T., Serenius-Sirve, S., \& Korkman, M. (1999). Lukilasse. Helsinki: Psykologien kustannus Oy.

Hornby, G., \& Woodward, L. (2009). Educational needs of school-aged children born very and extremely preterm: A review. Educational Psychology Review, 21, 247-266.

Hutchinson, E., De Luca, C., Doyle, L., Roberts, G., \& Anderson, P.for the Victorian Infant Collaborative Study Group. (2013). School-age outcomes of extremely preterm or extremely low birth weight children. Pediatrics, 131, e1053-e1061.

Johnson, S., Hennessy, E., Smith, R., Trikic, R., Wolke, D., \& Marlow, N. (2009). Academic attainment and special educational needs in extremely preterm children at 11 years of age. Archives of Disease in Childhood - Fetal and Neonatal Edition, 94 F283-F289.

Johnson, S., Wolke, D., Hennessy, E., \& Marlow, N. (2011). Educational outcomes in extremely preterm children: Neuropsychological correlates and predictors of attainment. Developmental Neuropsychology, 36, 74-95.

Kiechl-Kohlendorfer, U, Ralser, E, Peglow, U, Pehlboeck-Walser N. \& Fussenegger, B. (2013). Early risk predictors for impaired numerical skills in 5-year-old children born before 32 weeks of gestation. Acta Paediatrica, 102, 66-71.

Kirby, J., Georgiou, G., Martinussen, R., \& Parrila, R. (2010). Naming speed and reading From prediction to instruction. Reading Research Ouarterly, 45, 341-362.

Koponen, T., Aunola, K., Ahonen, T., \& Nurmi, J. -E. (2007). Cognitive predictors of singledigit and procedural calculation skills and their covariance with reading skill. Journa of Experimental Child Psychology, 97, 220-241.

Koponen, T., Salmi, P., Eklund, K., \& Aro, T. (2013). Counting and RAN: Predictors of arithmetic calculation and reading fluency. Journal of Educational Psychology, 105 $162-175$.

Landerl, K., \& Wimmer, H. (2008). Development of word reading fluency and spelling in a consistent orthography: An 8-year follow-up. Journal of Educational Psychology, 100 150-161.

Larroque, B., Ancel, P. -Y., Marchand-Martin, L., Cambonie, G., Fresson, J., Pierrat, V., ... Marret, S. (2011). Special care and school difficulties in 8-year-old very preterm children: The Epipage cohort study. PloS One, 6, e21361.

Lee, E., Yeatman, J., Luna, B., \& Feldman, H. (2011). Specific language and reading skills in school-aged children and adolescents are associated with prematurity after controlling for IQ. Neuropsychologia, 49, 906-1013.

Leijon, I., Ingemansson, F., Nelson, N., Wadsby, M., \& Samuelsson, S. (2016). Acto Paediatrica, 105, 60-68. 
Leppänen, M., Lapinleimu, H., Lind, A., Matomäki, J., Lehtonen, L., Haataja, L., \& the PIPAR Study Group (2014). Antenatal and postnatal growth and 5-year cognitive outcome in very preterm infants. Pediatrics, $133,63-70$

Lerkkanen, M. -K., Poikkeus, A. -M., \& Ketonen, R. (2006). ARMI: luku- ja kirjoitustaidon arviointimateriaali 1. luokalle. (ARMI - A tool for assessing reading and writing skills in Grade 1). Helsinki: WSOY.

Lervåg, A., \& Hulme, C. (2009). Rapid automatized naming (RAN) taps a mechanism that places constraints on the development of early reading fluency. Psychological Science, 20, 1040-1048

Lind, A., Korkman, M., Lehtonen, L., Lapinleimu, H., Parkkola, R., Matomäki, J., ... the PIPARI Study Group (2011). Cognitive and neuropsychological outcomes at 5 years of age in preterm children born in the 2000s. Developmental Medicine and Child Neurology, 53, 256-262.

Linsell, L., Malouf, R., Morris, J., Kurinczuk, J. J., \& Marlow, N. (2015). Prognostic factors for poor cognitive development in children born very preterm or with very low birth weight: A systematic review. JAMA Pediatrics, 169, 1162-1172.

Litt, J., Taylor, G., Klein, N., \& Hack, M. (2005). Learning disabilities in children with very low birthweight: Prevalence, neuropsychological correlates, and educational interventions. Journal of Learning Disabilities, 38, 130-141.

Litt, J., Taylor, G., Margevicius, S., Schluchter, M., Andreias, L., \& Hack, M. (2012). Academic achievement of adolescents born with extremely low birth weight. Acta Paediatrica, $191,1240-1245$.

Lowe, J., Erickson, S. J., MacLean, P., Duvall, S., Ohls, R., \& Duncan, A. F. (2014). Associations between maternal scaffolding and executive functioning in 3 and 4 olds born very low birth weight and normal birth weight. Early Human Development, 90, 587-593.

Lundequist, A., Böhm, B., Lagercrantz, H., Forssberg, H., \& Smedler, A. C. (2015). Cognitive outcome varies in adolescents born preterm, depending on gestational age, intrauterine growth and neonatal complications. Acta Paediatrica, 104, 292-299.

Martin, R. B., Cirino, P. T., Sharp, C., \& Barnes, M. (2014). Number and counting skills in kindergarten as predictors of grade 1 mathematical skills. Learning and Individual Differences, 34, 12-23.

Maunu, J., Kirjavainen, J., Korja, R., Parkkola, R., Rikalainen, H., Lapinleimu, H., ... the PIPAR Study Group (2006). Relation of prematurity and brain injury to crying behavior in infancy. Pediatrics, 118, 57-76.

McGrath, M., \& Sullivan, M. (2002). Birth weight, neonatal morbidities, and school age outcomes in full-term and preterm infants. Issues in Comprehensive Pediatric Nursing, 25, 231-254.

Munck, P., Niemi, P., Väliaho, A., Lapinleimu, H., Lehtonen, L., Haataja, L., \& the PIPAR Study Group (2012). Pre-reading skills of very-low-birth-weight prematurely born Finnish children. Child Neuropsychology, 18, 92-103.

Murray, A. L., Schratch, S. E., Thompson, D. K., Inder, T. E., Doyle, L. W., Anderson, J. F. I., \& Anderson, P. J. (2014). Neonatal brain pathology predicts adverse attention and processing speed outcomes in very preterm and/or very low birth weight children. Neuropsychology, 28, 552-562.

Nguyen, T., Tyler, T. W., Duncan, G. J., Clements, D. H., Sarama, J. S., Wolfe, C., \& Spitler, M. E. (2016). Which preschool mathematics competencies are most predictive of fifth grade achievement? Early Childhood Research Ouarterly, 36, 550-560.

Niemi, P., Nurmi, J. -E., Lyyra, A. L., Lerkkanen, M. -K., Lepola, J., Poskiparta, E., \& Poikkeus, A. M. (2011). Task avoidance, number skills and parental learning difficulties as predictors of poor response to instruction. Journal of Learning Disabilities, 44, 459-471.

Omizzolo, C., Schracth, S. E., Stargatt, R., Kidokoro, H., Thompson, D. K., Lee, K. J., .. Anderson, P. J. (2014). Neonatal brain abnormalities and memory and learning outcomes at 7 years in children born very preterm. Memory, 22, 605-615.

Östergren, R., \& Träff, U. (2013). Early number knowledge and cognitive ability affect early arithmetic ability. Journal of Experimental Child Psychology, 115, 405-421.

Poskiparta, E. (1995). Miten ehkäisen oppilaitteni luku- ja kirjoitusvaikeuden syntymisen? Kielellisen tietoisuuden kehittäminen 1. luokalla ryhmämuotoisena erityisopetuksena. (Developing linguistic awareness in Grade 1). Turku, Finland: University of Turku, Centre for Learning Research.

Pritchard, V., Clark, C., Liberty, K., Champion, P., Wilson, K., \& Woodward, L. (2009). Early school-based learning difficulties in children born very preterm. Early Human Development, 85, 215-224.

Pritchard, V., Bora, S., Austin, N., Levin, K., \& Woodward, L. (2014). Identifying very preterm children at educational risk using a school readiness framework Pediatrics, 134, e825-e832.
Puolakanaho, A., Ahonen, T., Aro, M., Eklund, K., Leppänen, P. H. T., Poikkeus, A. -M., ... Lyytinen, H. (2008). Developmental links of very early language and phonological skills to second grade reading outcomes strong to accuracy but only minor to fluency. Journal of Learning Disabilities, 41, 353-370.

Rickards, A., Kelly, E., Doyle, L., \& Callanan, C. (2001). Cognition, academic progress, behaviour and self-concept at 14 years of very low birth weight children. Journal of Developmental and Behavioral Pediatrics, 22, 11-18.

Saigal, S., Hoult, L. A., Streiner, D. L., Stoskopf, B. L., \& Rosenbaum, P. L. (2000). School difficulties at adolescence in a regional cohort of children who were extremely low birth weight. Pediatrics, 105, 325-331.

Samuelsson, S., Finnström, O., Flodmark, O., Gäddlin, P. -O., Leijon, I., \& Wadsby, M. (2006). A longitudinal study of reading skills among very-low-birth-weight children: Is there a catch-up? Journal of Pediatric Psychology, 31, 967-977.

Sasanguie, D., De Smedt, B., Defever, E., \& Reynvoet, B. (2012). Association between basic numerical abilities and mathematics achievement. British Journal of Developmental Psychology, 30, 344-357.

Schneider, W., Wolke, D., Schlagmüller, M., \& Meyer, R. (2004). Pathways to school achievement in very preterm and full-term children. European Journal of Psychology of Education, 19, 385-406.

Setänen, S., Haataja, L., Parkkola, R., Lind, A., Lehtonen, L., \& the PIPARI Study Group (2013). Predictive value of neonatal brain MRI on the neurodevelopmental outcome of preterm infants by 5 years of age. Acta Paediatrica, 102, 492-497.

Silvén, M., Poskiparta, E., Niemi, P., \& Voeten, M. (2007). Precursors of reading skill from infancy to first grade in Finnish: Continuity and change in a highly inflected language. Journal of Educational Psychology, 99, 516-531.

Simms, V., Gilmore, C., Cragg, L., Clayton, S., Marlow, N., \& Johnson, S. (2015). Nature and origins of mathematics difficulties in very preterm children: A different etiology than developmental dyscalculia. Pediatric Research, 77, 389-395.

Simms, S., Gilmore, C. Cragg L., Marlow, N., Wolke, D., \& Johnson, S. (2013). Mathematics difficulties in extremely preterm children: Evidence of a specific deficit in basic mathematics processing. Pediatric Research, 73, 236-244.

Stjernqvist, K., \& Svenningsen, N. W. (1999). Ten-year follow-up of children born before 29 weeks: Health, cognitive development, behaviour and school achievement. Acta Paediatrica, 88, 557-562.

Sucksdorff, M., Lehtonen, L., Chudal, R., Suominen, A., Joelsson, P., Gissler, M., \& Sourander, A. (2015). Preterm birth and poor fetal growth as risk factors of attention-deficit hyperactivity disorder. Pediatrics, 136, e599-e608.

Taylor, H. G., Klein, N., Anselmo, M. G., Minich, N., Espy, K. A., \& Hack, M. (2011). Learning problems in kindergarten students with extremely preterm birth. Archives of Pediatrics E' Adolescent Medicine, 165, 819-825.

Toll, S., Van der Ven, S., Kroesbergen, E., \& Luit, J. (2011). Executive functions as predictors of math learning disabilities. Journal of Learning Disabilities, 44, 521-532.

Torppa, M. Georgiou, G. K, Lerkkanen, M. -K, Niemi, P., Poikkeus, A -M., \& Nurmi, J. -E (2016). Examining the simple view of reading (SVR) model in a transparent orthography: A longitudinal study from kindergarten to grade 3. Merrill-Palmer Quarterly, $62,179-206$.

Tucker, J., \& McGuire, W. (2004). ABC of preterm birth - Epidemiology of preterm birth. British Medical Journal, 329, 675-678.

Wocadlo, C., \& Rieger, I. (2007). Phonology, rapid naming and academic achievement in very preterm children at eight years of age. Early Human Development, 83, 367-377.

Wolke, D., \& Meyer, R. (1999). Cognitive status, language attainment and prereading skills of 6 -year-old very preterm children and their peers: The Bavarian longitudinal study. Developmental Medicine and Child Neurology, 41, 94-109.

Wolke, D., Samara, M., Bracewell, M., \& Marlow, N. (2008). Specific language difficulties and school achievement in children born at 25 weeks of gestation or less. Journal of Pediatrics, 152, 256-262.

Wong, T., Taylor, H. G., Klein, N., Espy, K. A., Anselmo, M. G., Minich, N., \& Hack, M. (2014). Kindergarten classroom functioning of extremely preterm/extremely low birth weight children. Early Human Development, 90, 907-914.

Zhang, X., Koponen, T., Räsänen, P., Aunola, K., Lerkkanen, M. -K., \& Nurmi, J. -E. (2014). Linguistic and spatial skills predict early arithmetic development via counting sequence knowledge. Child Development, 85, 1091-1107. 